\title{
Pharmacovigilance and Pharmacoepidemiology
}

\section{Novel Phytochemical Constituents Identified from the Seeds of Mesua Ferrea $L$ and their Anticancer Activity}

\author{
Faizan DK ${ }^{1}$, Mehta $\mathrm{BK}^{1}$, Yasir $\mathrm{AL}^{2}, \operatorname{Masood} \mathrm{AK}^{3^{*}}$
}

\author{
Affiliation \\ ${ }^{1}$ School of Studies in Chemistry And Biochemistry, Vikram University, Ujjain, India \\ ${ }^{2}$ School of Studies in Chemistry, Barkatullah University, Bhopal, India \\ ${ }^{3}$ Department of Chemistry, Islamic University of Science and Technology (IUST), Awantipora Pulwama, India
}

*Corresponding author: Masood Ayoub Kaloo, Department of Chemistry, Islamic University of Science and Technology (IUST), Awantipora Pulwama, India, E-mail: masood.kaloo@ @islamicuniversity.edu.in

Citation: Faizan DK, Mehta BK, Yasir AL, Masood AK. Novel Phytochemical Constituents Identified from the Seeds of Mesua Ferrea L and their Anticancer Activity (2017) Pharmacovigilance and Pharmacoepidemiology 1: 1-4.

Received: Nov 11, 2017

Accepted: Dec 07, 2017

Published: Dec 12, 2017

Copyright: @ 92017 Faizan DK, et al., This is an open-access article distributed under the terms of the Creative Commons Attribution License, which permits unrestricted use, distribution, and reproduction in any medium, provided the original author and source are credited.

\begin{abstract}
Novel phytochemical constituents were isolated from the hexane extract of Mesua Ferrea L. seeds by using n-hexane. The two new compounds were identified by spectral (IR, ${ }^{1} \mathrm{H}$ NMR, ${ }^{13} \mathrm{C}$ NMR spectra, mass spectrum, elemental analysis) and chemical analysis. The compounds identified are 5-formyl-2-(propan-2-yl) phenyl acetate and 2, 4-diformyl-6-(propan-2-yl) phenyl acetate. Anticancer activities were assessed for the isolated compounds and have shown variable activity. These novel compounds are being reported for the first time.
\end{abstract}

Keywords: Phytochemical; Mesua Ferrea L; Seeds; Calophyllaceae; Anticancer activity.

\section{Introduction}

Mesua Ferrea L. commonly known as Nagkesar belongs to family Calophyllaceae. The plant is used medicinally in various ailments [1] The decoction of seeds of $M$. ferrea is given for the treatment of gastritis, bronchitis and to cure snake bite. Leaves of $M$. ferrea are antidote for snake bites and scorpion sting [2]. The different extracts of plants have shown anti- ulcer, anti venom, anti protozoal, anti cancer, anti-oxidant activities [3]. The present study reports the isolation and structural elucidation of two compounds isolated from the seeds of Mesua Ferrea L (Figure 1).

\section{Experimental}

\section{General procedures}

Melting points (MP) are uncorrected. ${ }^{1} \mathrm{H}$ NMR was recorded on 300 $\mathrm{MHz}$ Varian XL spectrometer, ${ }^{13} \mathrm{C}$ NMR spectra were recorded on Varian XL $75 \mathrm{MHz}$ spectrometer, IR spectra were recorded in $\mathrm{KBr}$ disk on Perkin Elmer-377 spectrometer, EIMS on Jeol-JMS D 300 mass spectrometer [4]. All chemical shifts (d) are given in ppm and $\mathrm{Me}_{4} \mathrm{Si}$ was used as internal standard. The carbon type $\left(\mathrm{CH}_{3}, \mathrm{CH}_{2}, \mathrm{CH}\right)$ was determined by DEPT experiments. Chemicals are of analyticalreagent grade and column chromatography was carried out on alumina grade III and TLC on silica gel G (CDH/Glaxo laboratories). Spots were visualized by exposure to iodine vapor or by spraying with $\mathrm{H}_{2} \mathrm{SO}_{4}$-vanillin solution followed by heating at $105 \_\mathrm{C}$ for $5 \mathrm{~min}$.<smiles>CC(=O)Oc1cc(C=O)ccc1C(C)C</smiles>

1. 5-formyl-2-(propan-2-yl) phenyl acetate

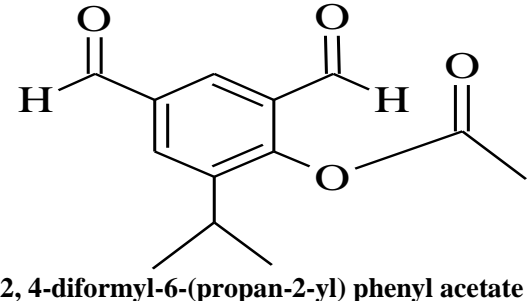

2. 2, 4-diformyl-6-(propan-2-yl) phenyl acetate

Figure 1: Chemical structures of compound1-2.

Citation: Faizan DK, Mehta BK, Yasir AL, Masood AK. Novel Phytochemical Constituents Identified from the Seeds of Mesua Ferrea L and their Anticancer Activity (2017) Pharmacovigilance and Pharmacoepidemiology 1: 1-4. 


\section{Plant material}

The seeds $(10 \mathrm{~kg})$ of $M$. ferrea $L$. were collected from the market of Ujjain city and were identified by the authorities of the Institute of Environment Management and Plant Science, Vikram University, Ujjain. A voucher specimen was deposited in the herbarium of the School of Studies in Botany, Vikram University, Ujjain, India.

\section{Extraction and isolation}

The seeds $(10 \mathrm{~kg})$ were shade dried, cleaned, coarsely powdered and extracted with hexane in soxhlet-extractor for $72 \mathrm{~h}$. The extract was concentrated by rotary evaporator to afford solid mass $(265 \mathrm{~mL})$. Usual work up yielded $(32 \mathrm{~g})$ solid extract which was separated by repeated column chromatography on alumina grade III. The column was eluted by gradient elution in increasing order of polarity like hexane, benzene, EtOAc and methanol. The fractions were collected in bulk and monitored by TLC. The residue $(6.8 \mathrm{~g})$ of hexane fraction was rechromatographed on alumina on the basis of increasing order of polarity of eluents. A well-stirred suspension of alumina III (100-150 g in petroleum ether 60-80) was poured into the column $(150 \mathrm{~cm}$ long and $50 \mathrm{~mm}$ in diameter). When the absorbent was well settled, the excess of hexane was allowed to pass through the column. With silica gel in hexane, the mass was made into a slurry and digested in a well stirred column. The column was successively eluted with the hexane, benzene, EtOAc and methanol and their mixtures of increasing polarity. The column hexane fraction (Fr. No. 1-10) afforded one compound in pure form designated as A23, column of hexane: benzene (1:1, v/v, Fr. No. 28-34) afforded another compound in pure form designated as A24.

\section{Screening of Anticancer Activity}

The anticancer activities of the compound 1 and 2 of $M$. ferrea $L$. (Seeds) [5] against the three Cancerous cell lines were undertaken by using MTT (3-(4,5-dimethylthiazol-2-yl)-2,5-diphenyltetra zolium bromide) assay. The three tested cancer cell lines were Hek (Human embryonic kidney cell lines), IMR-32 (Human neuroblastoma) and C6 (Rat glioblastoma). All the three cell lines were maintained in DMEM (Media) supplemented with $10 \%$ fetal bovine serum (FBS) and $1 \%$ antibiotic (Pencillin/ Streptomycin) [5]. All the cell lines were cultured in $75 \mathrm{~cm}^{2} \mathrm{~T}$ - flask and maintained at $37^{\circ} \mathrm{C}$ in $5 \%$ carbon dioxide humidified incubator for 24 hours. The MTT Assay is based on the protocol illustrated by Mosmann [6] and was executed in 12- well flat bottom plates. The varying concentrations of compounds $5,10,15,20$, $25,30,35,40,45,50$ and $55 \mu \mathrm{g} / \mathrm{ml}$ were prepared by a serial dilution method. After 24 hours $300 \mu$ of MTT solution and PBS (Phosphate buffer saline) was added to all the wells and incubated for 3 hours in a $5 \% \mathrm{CO}_{2}$ humidified incubator. $300 \mu \mathrm{l}$ of DMSO (Solubilization buffer) were added to each well and incubated for 10 minutes. The absorbance of each well was determined using a microplate reader at $550 \mathrm{~nm}$. A graph of cell viability versus concentrations was plotted for each compound. The half maximal inhibitory concentration $\left(\mathrm{IC}_{50}\right)$ values were obtained from the plotted graph. Further dilutions will only be performed on the compounds with $\mathrm{IC}_{50}$ values less than $15 \mu \mathrm{g} / \mathrm{ml}$. Three independent experiments were conducted to assure the accuracy of the results.

\section{Compound 1}

Designation: 5-formyl-2-(propan-2-yl) phenyl acetate, Elemental analysis: Calculated for $\mathrm{C}_{12} \mathrm{H}_{14} \mathrm{O}_{3}, \mathrm{C}=69.88 \%, \mathrm{H}=6.84 \%, \mathrm{O}=23.27$ $\%$, Observed values $\mathrm{C}=69.60 \%, \mathrm{H}=6.94 \%, \mathrm{O}=23.11 \%$, Molecular formula: $\mathrm{C}_{12} \mathrm{H}_{14} \mathrm{O}_{3}$, Solubility: $\mathrm{CDCl}_{3}$, Molecular ion peak: $\mathrm{M}^{+} 206$, TLC solvent system: Chloroform: methanol: acetic acid (6:4:0.5, v/v), Recrystallization:Chloroform:Methanol, State : Solid, IR spectrum ( $\left.\mathbf{m} \mathbf{m a x}, \mathbf{K B r}, \mathbf{~ c m}^{-1}\right)$ 3382, 2967, 1603, 1429, 1216, 1044, 925, 761, 670 $\mathrm{cm}^{-1},{ }^{1} \mathbf{H}$ NMR spectrum (300 $\left.\mathbf{M H z}, \mathbf{C D C l}_{3}, \mathbf{T M S}, \delta\right) \delta 10.10$
(s,CHO), $\delta 7.69$ and $7.26\left(\mathrm{~m}, 3 \mathrm{H}\right.$ of benzene), $\delta 2.59\left(\mathrm{~s},-\mathrm{CO}_{-} \mathrm{CH}_{3}\right), \delta$ 1.26 (d, $2 \mathrm{CH}_{3}$ of isopropyl), $\delta 3.2\left(\mathrm{~m},-\mathrm{CH}\right.$ of isopropyl), ${ }^{13} \mathbf{C ~ N M R}$ spectrum $\left(\mathbf{7 5} \mathbf{~ H z}, \mathbf{C D C l}_{3}\right.$, ppm) $133.5,131.6,127.1,141.7,192.8$, $160.0,22.1,12.1 \mathrm{ppm}$, ESI-MS spectrum $\left(\mathbf{m} / \mathbf{z}\right.$, rel. inte.) $206\left[\mathrm{M}^{+}\right]$, $198,179,109$.

\begin{tabular}{|l|l|}
\hline \multicolumn{2}{|l|}{ C6 Glioblastoma) } \\
\hline Comp. 1 & Comp. 2 \\
\hline 0.497 & 0.393 \\
\hline 0.470 & 0.364 \\
\hline 0.453 & 0.354 \\
\hline 0.420 & 0.324 \\
\hline 0.400 & 0.311 \\
\hline 0.384 & 0.294 \\
\hline 0.344 & 0.280 \\
\hline 0.330 & 0.270 \\
\hline 0.311 & 0.251 \\
\hline 0.274 & 0.241 \\
\hline 0.267 & 0.235 \\
\hline 0.261 & 0.230 \\
\hline
\end{tabular}

Table 1: Anticancer activity of compound 1 and 2 of $M$. ferrea $L$. (Seeds) against C6 (Rat glioblastoma).

\begin{tabular}{|l|l|}
\hline \multicolumn{2}{|c|}{ HEK-T } \\
\hline Comp. 1 & Comp. 2 \\
\hline 0.589 & 0.529 \\
\hline 0.541 & 0.501 \\
\hline 0.431 & 0.410 \\
\hline 0.414 & 0.380 \\
\hline 0.382 & 0.351 \\
\hline 0.371 & 0.344 \\
\hline 0.330 & 0.310 \\
\hline 0.311 & 0.281 \\
\hline 0.274 & 0.270 \\
\hline 0.267 & 0.260 \\
\hline 0.262 & 0.253 \\
\hline 0.247 & 0.247 \\
\hline
\end{tabular}

Table 2: Anticancer activity of compound 1 and 2 of $M$. ferrea $L$. (Seeds) against Hek (Human embryonic kidney cell lines).

\section{Compound 2}

Designation: 2, 4-diformyl-6-(propan-2-yl) phenyl acetate, Elemental analysis: Calculated for $\mathrm{C}_{13} \mathrm{H}_{14} \mathrm{O}_{4}, \mathrm{C}=66.66 \%, \mathrm{H}=6.02 \%, \mathrm{O}=27.32$ $\%$, Observed values $\mathrm{C}=67.49 \%, \mathrm{H}=6.00 \%, \mathrm{O}=26.12 \%$, Molecular formula: $\mathrm{C}_{13} \mathrm{H}_{14} \mathrm{O}_{4}$, Solubility: $\mathrm{CDCl}_{3}$, Molecular ion peak: $\mathrm{M}^{+} 234$, TLC solvent system: Benzene: ester: acetic acid (9:1:0.5), 
Recrystallization: Chloroform: Methanol, State: Solid, IR spectrum ( $\mathbf{f m a x}, \mathbf{K B r}, \mathbf{~ c m}^{-1}$ ) 3022, 1638, 1679, 1436, 1296, 1216, 759, 669, 595, $553 \mathrm{~cm}^{-1},{ }^{1} \mathbf{H}$ NMR spectrum (300 MHz, CDCl 3 , TMS, $\left.\delta\right) \delta 7.26, \delta$ $7.93(2 \mathrm{~s}, 2 \mathrm{H}$ of benzene), $\delta 10.27$ (s, Ar-CHO), $\delta 10.48$ (s, Ar-CHO), $\delta$ $2.93\left(\mathrm{~s}, \mathrm{CO}-\mathrm{CH}_{3}\right), \delta 1.24\left(\mathrm{~d}, 2 \mathrm{CH}_{3}\right), \delta 3.34\left(\mathrm{~m}, \mathrm{CH}\right.$ of isopropyl), ${ }^{13} \mathbf{C}$ NMR spectrum $\left(\mathbf{7 5} \mathbf{~ H z}, \mathbf{C D C l}_{3}, \mathbf{p p m}\right)$ 126.4, 136.3, 136.0, 117.9, 144.1, 190.24, 195.81, 165, 22.1, $12.1 \mathrm{ppm}$, ESI-MS spectrum $(\mathbf{m} / \mathbf{z}$, rel. inte. ) $234\left[\mathrm{M}^{+}\right], 275,207,179,127$.

\begin{tabular}{|l|l|}
\hline \multicolumn{2}{|c|}{ IMR32 } \\
\hline Comp. 1 & Comp. 2 \\
\hline 0.572 & 0.530 \\
\hline 0.560 & 0.501 \\
\hline 0.489 & 0.410 \\
\hline 0.471 & 0.380 \\
\hline 0.450 & 0.351 \\
\hline 0.440 & 0.341 \\
\hline 0.411 & 0.310 \\
\hline 0.391 & 0.280 \\
\hline 0.360 & 0.271 \\
\hline 0.352 & 0.260 \\
\hline 0.347 & 0.251 \\
\hline 0.331 & 0.247 \\
\hline
\end{tabular}

Table 3: Anticancer activity of compound 1 and 2 of $M$. ferrea $L$. (Seeds) against IMR-32 (Human neuroblastoma).

\section{Results and Discussions}

The novel compounds were identified mainly by their IR, ${ }^{1} \mathrm{H}$ NMR, ${ }^{13} \mathrm{C}$ NMR and Mass spectrometry analysis.

\section{Compound 1}

IR spectrum ( $\left.\mathbf{~ m a x}, \mathbf{K B r}, \mathbf{~ c m}^{-1}\right)$ The absorption bands at 3382, 2967, $1429,1216 \mathrm{~cm}^{-1}$ were due to the presence of $-\mathrm{CH}$ stretching and bending vibrations, while the absorption bands at 761, 862, 1429, 1603 and $1216 \mathrm{~cm}^{-1}$ indicated the aromatic nature of A23 $[7,8]$.

${ }^{1} \mathrm{H}$ NMR spectrum $\left(300 \mathrm{MHz}, \mathbf{C D C l}_{3}, \mathbf{T M S}, \boldsymbol{\delta}\right)$ The signal at $\delta 10.10$ showed the presence of $-\mathrm{CHO}$ group in the molecule. The multiplets at $\delta 7.69$ and $\delta 7.26$ showed the presence of benzene ring in the molecule. Hence the molecule is aromatic aldehyde. The singlet at $\delta 2.59$ was due to acetyl group. Doublet at $\delta 1.261$ was assigned to $-\mathrm{CH}$ group and a multiplet at $\delta 3.2$ showed the presence of isopropyl group in the molecule [9].

${ }^{13} \mathrm{C}$ NMR spectrum (75 $\mathbf{~ H z}, \mathbf{C D C l}_{3}$, ppm) The ${ }^{13} \mathrm{CNMR}$ suggests that it consists of $12 \mathrm{C}$ skeleton. The peaks at 133.5, 131.6, 127.1, 141.7 $\mathrm{ppm}$ were due to benzene nucleus in the molecule. The peak observed at $192.8 \mathrm{ppm}$ was due to $-\mathrm{CHO}$ group in the molecule [10]. The carbonyl group of acetyl group was resonated at $160.0 \mathrm{ppm}$ and the peaks observed at 22.1 and12.1 ppm were due to methane and methyl carbons of isopropyl group present in the molecule.

ESI-MS Spectrum (m/z, rel. inte. ) The ESIMS showed the molecular ion peak at m/z $206\left[\mathrm{M}^{+}\right]$suggesting its molecular formula as $\mathrm{C}_{12} \mathrm{H}_{14} \mathrm{O}_{3}$.
The other fragments were obtained at $\mathrm{m} / \mathrm{z}$ 198, 179,109 were also consistent with the proposed structure. Thus on the basis of above spectral evidences, the compound was identified and characterized as 5-formyl-2-(propan-2-yl) phenyl acetate [11].

\section{Compound 2}

IR spectrum ( $\left.\mathbf{K m a x}, \mathbf{K B r}, \mathbf{c m}^{-1}\right)$ The IR spectrum showed strong bands at $3022 \mathrm{~cm}^{-1}$ and $1436 \mathrm{~cm}^{-1}$ due to $\mathrm{C}-\mathrm{H}$ stretching and $\mathrm{C}-\mathrm{C}$ ring stretching. The absorption band appeared at $1638 \mathrm{~cm}^{-1}$ showed the presence of carbonyl group of aldehyde in the molecule. Absorption band at $1679 \mathrm{~cm}^{-1}$ indicates $-\mathrm{O}-\mathrm{CO}-\mathrm{CH}_{3}$ functionality in the molecule. Absorption bands at 1296 and $1216 \mathrm{~cm}^{-1}$ were due to C$\mathrm{O}$ stretching of aldehyde and carbonyl of acetyl group. The absorption bands at $759,669,595$ and $553 \mathrm{~cm}^{-1}$ were due to out of plane C-H bending [11].

${ }^{1} \mathrm{H}$ NMR spectrum (300 $\mathrm{MHz}, \mathrm{CDCl}_{3}$, TMS, $\left.\delta\right){ }^{1} \mathrm{H}$ NMR spectrum in $\mathrm{CDCl}_{3}$ showed that it is a naturally acetylated polar aromatic compound having aldehyde group. Two aromatic protons were resonated at $\delta 7.26-7.93$ as a sharp singlet, which indicates that other positions were derivatized naturally. The peak appeared at $\delta 10.27$ as sharp singlet indicates the presence of aldehyde group, in benzene nucleus. The peak appeared at $\delta 10.48$ which is deshielded, indicates that two aldehyde groups are present nearby acetoxyl group. The acetyl $\left(-\mathrm{CO}-\mathrm{CH}_{3}\right)$ methyl group was resonated at $\delta 2.93$ as a sharp singlet. It is more deshielded than ketone, which means it is attached as -O-CO$\mathrm{CH}_{3}$. Two methyl groups were resonated at $\delta 1.24$ as a doublet and methane proton was at $\delta 3.34$ as a multiplet, which indicates that isopropyl group is present in benzene nucleus [12].

${ }^{13} \mathrm{C}$ NMR spectrum (75 $\left.\mathbf{H z}, \mathbf{C D C l}_{3}, \mathbf{p p m}\right)$ The ${ }^{13} \mathrm{C}$ NMR spectrum suggested that it consists of $18 \mathrm{C}$ skeleton. The peaks at 126.4, 136.3, $136.0,117.9,144.1 \mathrm{ppm}$ were due to benzene nucleus in the molecule. The peaks observed at 190.24 and 195.81 were due to aldehydic group in the molecule, one is deshielded (195.81) due to the presence of -O$\mathrm{CO}-\mathrm{CH}_{3}$ group present at ortho-position to it. The carbonyl group of acetyl was resonated at $165 \mathrm{ppm}$ and the peaks observed at 22.1 and $12.1 \mathrm{ppm}$ suggested that isopropyl group is present in the molecule.

ESI-MS spectrum ( $\mathbf{m} / \mathbf{z}$, rel.inte) The molecular ion peak of A24 was found at $234\left[\mathrm{M}^{+}\right]$which suggested its molecular formula as $\mathrm{C}_{13} \mathrm{H}_{14} \mathrm{O}_{4}$. Other abundant fragments were obtained at $\mathrm{m} / \mathrm{z}$ 275,207,179 and 127 were also consistent with the proposed structure. Thus on the basis of above spectral data compound A24 has been characterized as 2, 4diformyl-6-(propan-2-yl) phenyl acetate [11]

\section{Screening of Anticancer Activity}

The novel compounds ( 1 and 2 ) of $M$. ferrea $L$. (Seeds) showed significantly anticancer activities against Hek (Human embryonic kidney cell lines), IMR-32 (Human neuroblastoma) and C6 (Rat glioblastoma). Among the two compounds, compound 1 showed strong anticancer activity against the three tested cancer cell lines while as compound 2 showed moderate anticancer activity. The results are being given in Table No. 1, 2 and 3.

\section{Conclusion}

From the survey of the literature to the best of our knowledge the compounds were novel and are being reported first time by us from seeds of $M$. ferrea $L$. and further examination of the constituents of this plant is currently in progress.

Citation: Faizan DK, Mehta BK, Yasir AL, Masood AK. Novel Phytochemical Constituents Identified from the Seeds of Mesua Ferrea L and their Anticancer Activity (2017) Pharmacovigilance and Pharmacoepidemiology 1: 1-4. 


\section{Acknowledgements}

Authors gratefully acknowledge Natural Product Research Centre (SOS Chemistry) Vikram University Ujjain, CDRI Lucknow and IUST Srinagar (J\&K) for providing research infrastructure, use of different techniques like IR, NMR and mass spectra and checking out their anticancer activity.

\section{References}

1. Ambasta SP. The useful plants of India (1994) Publication and information directorate, CSIR, New Delhi.368.

2. Garg S, Sharma K, Ranjan R, Attri P, Mishra P. In vivo antioxidant activity and hepatoprotective effects of methanolic extract of Mesua ferrea Linn (2009) Int J Pharm Tech. Res 1: 1692-1696.

3. Sahni KC. The book of Indian trees (1998) Bombay natural history society, USA

4. Ali MA, Sayeed MA, Bhuiyan MSA, Sohel FI, Yeasmin MS. Antimicrobial screening of Cassia fistula and Mesua ferrea (2004) J Med Sci 4: 24-29.
5. Chakraborty DP, Purkayastha M, Bose PK. On the antibiotic properties of some constituents of Mesua ferrea Linn (1958) N. I. S. Junior Research Fellow 25: 8-11.

6. Mosmann T. Rapid colorimetric assay for cellular growth and survival: application to proliferation and cytotoxicity assays (1983) J Immunol Methods 65: 55-63.

7. Bellamy LJ. The Infrared Spectra of Complex Molecules (1975) Chapman and Hall, UK.

8. Dyer JR. Application of Absorption Spectroscopy of Organic Compounds (1984) Prentice and Hall of India Ltd 1: 33-38.

9. Jackson LM, Sternhill S. Application of Nuclear Magnetic Resonance Spectroscopy in Organic Chemistry (1969) Pergamon Press, USA 5: 48.

10. Crespo-Ortiz MP, Wei MQ. Antitumor activity of Artemisinin and its derivatives: from a well known antimalarial agent to a potential anticancer drug (2012) J. Biomed. And Biotechnol.

11. Harborne JB. Phytochemical Methods: A Guide to Modern Techniques of Plant Analysis. 3rd Edn. (1998) Chapman and Hall, UK 1: 129-138,302.

12. Bahl BS, Bahl A. A Text Book of Organic Chemistry 13th Edn (1992) Schand and Company Ltd, India 11-14.

Citation: Faizan DK, Mehta BK, Yasir AL, Masood AK. Novel Phytochemical Constituents Identified from the Seeds of Mesua Ferrea L and their Anticancer Activity (2017) Pharmacovigilance and Pharmacoepidemiology 1: 1-4. 